\title{
Research on Transformation Strategy of Enterprise Human Resource Management in Big Data Era
}

\author{
Ke Zhang ${ }^{1, a}$, Pei $\mathrm{Xu}^{1, \mathrm{~b}}$ \\ ${ }^{1}$ Beijing Normal University, Beijing 100875, China. \\ azhangkebnu@163.com, b381102168@qq.com
}

\begin{abstract}
With the continuous innovation of modern computer science and technology and communication technology, human society has gradually shifted from the traditional industrial era to the information age and the era of big data. The arrival of the big data era brings more opportunities and challenges to the business and development of the enterprise. Relying on the background of the big data age, it is of great significance to apply the large data technology to the human resource management of the enterprise. Based on the background of big data era, this paper explores the strategy of enterprise human resource management reform. The author believes that the application of large data technology in the human resource management practice of enterprises can effectively promote the reform and development of enterprise human resource management.
\end{abstract}

Keywords: Big data, human resource management, change strategy.

\section{Introduction}

At this stage, the society has gradually transferred to the era of comprehensive information and large data. Under such a broad background, large data technology has a profound impact on the development of all walks of life. In the era of large data, the traditional human resource management model has exposed a series of problems and short boards, such as backward management concept, leading to the loss of talent; management methods lag behind, resulting in low efficiency. The application of large data technology to the human resources of enterprises is helpful to promote the development and innovation of enterprise human resource management, and then lay a good foundation for the talents reserve of the enterprise. The academic circle divides human resource management into six modules, which are human resource planning, recruitment and allocation, labor relations management, training and development, performance management and compensation and welfare management. It should be realized that these six modules are the core elements of the enterprise human resource management, and are also the key elements to be considered in the human resource management of the enterprise in the era of large data. This article will focus on these six aspects, and explore the transformation strategy of human resource management in the era of big data.

\section{Interpretation of the Meaning of Large Data}

Big data, big data, is called huge data and massive data. In fact, large data can be classified as information assets. This information asset is different from traditional assets, and it needs a set of powerful information technology to handle and configure it to play a full role. Large data processing needs to be applied to major data technology, including data mining technology, large-scale parallel processing technology, database technology, distributed database technology and cloud computing technology. The strategic significance of the application of large data technology is very significant. On the one hand, it can help the enterprises in need to obtain massive information resources and lay the foundation for the enterprise to carry out various work. On the other hand, it can select and deal with all the data professionally, and obtain the most valuable information resources from it. We can regard big data as an industry, and whether the big data industry can make profit or profit depends on the application of big data technology. In the era of big data, all kinds of data resources are continuing to expand and grow, which will have a crucial impact on the future development of enterprises. Many companies with keen sense of smell have been deeply aware of the importance of big data, such as Guotai Junan, galactic securities and other institutions that have written large data into their designated recommended investment reports. 


\section{Strategy Analysis of Enterprise Human Resource Management Reform under the Background of Big Data}

\subsection{The Meaning of Human Resource Management in Enterprises}

The so-called human resource management refers to a series of processes to lay the foundation for the realization of the strategic objectives of the enterprise according to the needs of its own development strategy and the allocation of human resources according to a certain plan. Enterprise human resources management covers a wide range, involving employee recruitment, training, appointment, assessment, reward and adjustment, and many other aspects. Fully mobilizing the enthusiasm of employees, scientifically arranging staff work and maximizing the potential of employees is an important part of human resources management in enterprises. The academic circle divides the work of human resource management into six elements, which are human resource planning, recruitment and allocation, labor relations management, training and development, performance management and compensation and welfare management. In the era of large data, enterprises should also look for the combination of these six elements to the large data technology and human resource management, reform and innovate the traditional human resource management, in order to improve the quality and efficiency of the enterprise human resource management.

\subsection{The Innovation of Human Resource Planning and the Allocation of Talent Recruitment}

Human resource planning is the first step of enterprise human resource management. Scientific and reasonable human resource planning will help enterprises to reduce the cost of human resources and maximize the income. The traditional enterprise human resource planning is often in order to follow the rules, the malpractice of this model is very obvious, its management mode is rigid, the management efficiency is not high, it is not conducive to the comprehensive development of the enterprise. In the era of large data, enterprises can use large data technology to establish a "personnel database" of an enterprise itself. According to the development of the needs of the enterprise, the human resources of the enterprise can be controlled in an appropriate range. All the employees' professional information is entered into it. Through data analysis and comparison, the human resources are applied to the required business to ensure that people have their own talents and things. Recruitment is an important way for enterprises to inject fresh human resources and should be taken seriously. Enterprises can make use of big data technology to achieve two-way choice between job seekers. The enterprise can release the recruitment demand on the large recruitment platform, the information of all job seekers through the computer into the database, according to the corresponding conditions to select the job seeker, select the best employment. When selecting job seekers, they need to be professionally responsible for ensuring the integrity and authenticity of the information. For recruitment and recruitment, a set of special data analysis and testing system can be designated to determine the applicable position of talents and predict the potential of talent development so as to adjust the human resources in the future.

\subsection{Labor Relations and Salary Management}

In general, the labor contract signed between employees and enterprises has defined the relationship between the two parties. However, in order to improve employee loyalty to enterprises and prevent brain drain, it should be more humane in the process of labor management relations. Relying on Internet technology, we can gradually adjust and change the way employees work, improve work processes, and standardize business at the same time. Salary management is also an important link in the management of human resources. On the one hand, the scientific design of salary management system is the affirmation for the hard work and pay of the employees. On the other hand, the existence of the salary management system is also an effective measure to motivate the employees to work hard. The enterprise can use the database technology to record the daily work situation and business performance of the employees, make a scientific evaluation system. Through screening, analysis and comparison, we can determine the employees who have outstanding contribution to the 
development of the enterprise and gradually increase the motivation of the employees, which will be the benchmarks and example and improve the whole. Employees' enthusiasm for work.

\subsection{Staff Training and Development and Performance Management}

Employee training is an important measure to give full play to the potential of employees and improve their working ability. It is also an important part of human resources management in enterprises. The author believes that employees' training and performance management can be combined with large data technology to record and analyze employees' daily work data, performance data, and developmental data to measure the staff's comprehensive ability. According to the employee's professional characteristics (job requirements), they are targeted to the staff. To improve the work quality and efficiency of employees, we should train our business capability. The traditional performance management system has a certain lag, which can not fully reflect the relationship between the workload and the performance of the staff; at the same time, the personnel responsible for performance management may lead to a certain "misunderstanding" in performance management because of the supervisor's conjecture. In order to make a more comprehensive and scientific judgment of employee performance, we should consider the introduction of large data technology in the performance management, and adopt two sets of evaluation systems for staff's attendance, workload, and work performance, such as objective evaluation and subjective evaluation, and the proportion of the two can be based on the actual situation of the enterprise. Adjust. Among them, the objective evaluation is completed by the computer, which mainly evaluates some indicators that are easy to be data-based, such as attendance, business completion, and the subjective evaluation is responsible for the performance management personnel, and comprehensive evaluation of the working status of the employees.

\section{Summary}

To sum up, under the background of big data era, the traditional enterprise human resource management mode needs to rely on big data technology. This paper explores the reform strategy of human resource management in the era of large data, and holds that only the continuous promotion of the integration of large data technology and enterprise human resource management can guarantee the work quality, efficiency and foresight of the enterprise human resource management.

\section{References}

[1]. Li Qiang. Strategy of enterprise human resource management reform in big data era [J]. management, 2016 (7).

[2]. Wang Aihua. Thoughts on the transformation of enterprise human resource management in the era of big data $[\mathrm{J}]$. modern state-owned enterprise research, 2016 (14).

[3]. Guo Hang Yuan. Innovation and strategy analysis of enterprise human resource management in big data era $[\mathrm{J}]$. enterprise reform and management, 2018 (8).

[4]. Niu Bai Chen. Exploration of enterprise human resource management reform in big data era [J]. China collective economy, 2017 (15): 76-77.

[5]. Wang Haibo. Exploration of transformation strategy of enterprise human resource management in big data era $[\mathrm{J}]$. technology and innovation, 2016 (8): 55-56. 